\title{
The Implementation of Non-Smoking Area Qanun (Regulation) in West Aceh Health Office
}

\author{
${ }^{1}$ Veni Nella Syahputri, ${ }^{1}$ Fitriani Fitriani, ${ }^{1}$ Teungku Nih Farisni, ${ }^{1}$ Yarmaliza Yarmaliza, ${ }^{1}$ Fitrah \\ ${ }^{1}$ Reynaldi, ${ }^{1}$ Darmawi Darmawi \\ Faculty of Public Health, Universitas Teuku Umar, Aceh, Indonesia \\ Corresponding author's email: veninellasyahputri@utu.ac.id
}

Submitted: 20/08/2019 Revised: 22/09/2019 Accepted: 04/10/2019

How to cite this article:

Syahputri, V., Fitriani, f., Farisni, T., Yarmaliza, Y., Reynaldi, F., \& Darmawi, D. (2019). The implementation of non-smoking area qanun (regulation) in West Aceh Health Office. J-KESMAS, $6(2), 57-73$

\begin{abstract}
West Aceh Regency Regulation (Qanun in Indonesia) Number 14 of 2015 concerning on NonSmoking Areas is a regional regulation that regulates non-smoking areas in West Aceh Regency with the aim of protecting public health from the dangers caused by cigarette smoke. The purpose of this study was to determine the implementation of the Edwar III Model on aspects of communication clarity, aspects of authority, aspects of disposition or attitude, and aspects of Standard Operating Procedures (SOP) in implementing Non-Smoking Area Qanun in the West Aceh Health Office. The methodology used in this study is qualitative research in which the data collection is done by interviewing selected informants by purposive sampling, namely 2 (two) main informants and 5 (five) triangulation informants. The results of this study showed that: in the aspects of communication-the head office has provided the information about Non-Smoking Area Regulation (Qanun). The aspect of authority: the implementation of regulation is determined as head office authority. The attitude aspects: employees still have an attitude that incompliant with the implementation of the NonSmoking Area Regulation (Qanun). The Standard Operating Procedures (SOP) aspect is that the Health Office does not have an SOP yet to regulate the Health Office internally in implementing the Non-Smoking Area Regulation (Qanun). The conclusion of this study is that the implementation of Non-Smoking Areas Regulation (Qanun) in the Health Office is still not comprehensively implemented due to the absence of guidance, supervision and punishments for violators of NonSmoking Area Regulation (Qanun). Therefore, it is recommended that head office be able to implement supervisors, supervision, and punishments to violators of Non-Smoking Areas Regulation (Qanun) thus the healthy circumstance can be created in working area.
\end{abstract}

\section{Keywords}

Implementation; Qanun; non-smoking area; communication; authority; attitude

\section{Background}

Law No. 36 of 2009 concerning Health states that the goal of health development is to increase awareness, willingness and ability to live healthy for everyone in order to realize the highest degree of public health. The government is obliged to organize various health efforts for all Indonesian citizens where one of its efforts is safeguarding addictive substances, as 
stipulated in the seventeenth part of Law Number 36 of 2009 that cigarettes are addictive substances that need security in their use so as not to interfere and endanger the health of yourself, others and the surrounding environment.

Smoking for people in everyday life is common and commonplace, favored by men and women including children, adolescents, adults. Until now there has been no significant decline in the number of smokers and the number of people exposed to cigarette smoke (Paper, 2012). According to the results of Riskesdas in 2013 that the proportion of population aged $\geq 15$ years who smoked and chewed tobacco tended to have an increasing number since 2007 (34.20\%), 2010 (34.70\%) and in 2013 it was 36.30\%. (Riskesdas, 2013). The World Health Organization (WHO) recommends that a $100 \%$ smoke-free environment is the only effective way to reduce exposure to secondhand smoke in the room (WHO, 2011).

Smoking is one of the lifestyle changes caused by the effects of globalization that can affect human health. According to WHO data (World Health Organization), the deaths of 6 million people each year are caused by smoking habits, including passive smoking of 600,000 who die from exposure to cigarette smoke. If this continues, it is predicted that by the year 2030 there will be 8 million deaths each year, of which $80 \%$ occur in poor and developing countries. Monitoring of smoking habits according to WHO research results in the On The Global Tobacco Epidemic Report (2011) shows that smoking does not only occur in developed countries, but also occurs in developing countries in the Continent of Africa and Asia (WHO, 2011).

From 1970 to 2000, cigarette consumption in Indonesia increased 7 times from around 33 billion cigarettes. In the period 2005 to 2008 there was a sharp increase in cigarette consumption, namely 214 billion in 2005 to 240 billion cigarettes in 2008 . The WHO report in 2008 placed Indonesia as the third largest country in terms of the number of smokers. From various literature, it is stated that the risk of smoking in women is a decrease or delay in the ability to conceive. Riskesdas data shows that 169 million people are exposed to passive smoking and $40.5 \%$ of the population of all ages (91 million) are exposed to cigarette smoke in their homes, and half of these are children. Other data from GYTS in 2009 showed that a quarter of students were exposed to cigarettes in public places (Paper, 2012).

Law No. 36 of 2009 concerning Health, expressly states the establishment of non-smoking regulations by the Regional Government in the Seventeenth Section of Article 115. In addition, the establishment of non-smoking areas by the Regional Government is confirmed by Government Regulation No. 19/2003 Safeguarding Cigarettes for Health in Part Six Article 25 which gives authority to the Regional Government to realize an area without smoking.

One other breakthrough made by the government is the formulation of a MOU (Memorandum of Understanding) between the Ministry of Home Affairs and the Ministry of Health which emphasizes the implementation of Non-Smoking Areas. A joint regulation between the Minister of Health and the Minister of Home Affairs was written in a letter number 188 / MENKES / PB / I / 2011 and Number 7 of 2011 concerning Guidelines for the Implementation of Non-Smoking Areas. This joint regulation actually mentions the existence of sanctions for violators, but still needs to be strengthened with operational guidelines and consistent implementation in the field (Paper, 2012).

At present the policy of prohibiting smoking in public places in Indonesia is a regional policy, although not all regions have made this policy. Based on data from the Indonesian Ministry of 
Health (2013) the districts / cities that have or carry out the most regulation on Non-Smoking Areas are in Yogyakarta as many as 4 Regencies / Cities (80\%) and West Sumatra with 14 Regencies / Cities (73.68\%). Whereas the Aceh Province from the Ministry of Health data shows that the implementation of the new KTR regulations reached 5 Regencies / Cities $(21.74 \%)$.

West Aceh Regency Qanun Number 14 of 2015 concerning Non-Smoking Areas is a regional regulation that regulates non-smoking areas in West Aceh Regency with the aim of protecting public health from the dangers of cigarette smoke, providing clean and healthy space and environment for the community, protecting public health general impact

bad smoking both directly and indirectly, and suppress the growth rate of novice smokers. In the Qanun it is stated that every person is prohibited from smoking, selling or promoting cigarettes in the area without cigarettes.

To implement Qanun on KTR, it is regulated about the need for guidance and supervision, as stated in article 14 in the QTR of KTR which states that guidance and supervision is carried out by SKPK which has duties and functions in accordance with the place declared nonsmoking area. Coaching is carried out with the aim of developing a community for healthy behavior. This training is carried out with guidance or counseling. While supervision is carried out with the aim of curbing and giving sanctions to people suspected of violating the Qanun of Non-Smoking Areas.

Interview with the Head of the Health Promotion Section, information was obtained that the Health Office is a government institution that pioneered health policies and the implementation of effective health programs that are expected to improve public health levels. Likewise with the West Aceh District Health Office, which is expected to be a pioneer in the implementation of health policies and as an example for institutions below or other institutions. Therefore, the existence of the West Aceh District Health Office is also expected to be able to spearhead any government policy, especially regarding the implementation of the No Smoking Zone Qanun.

The initial survey conducted by the author on 5 employees at the West Aceh District Health Office office revealed that employees already knew and supported the implementation of the Qanun KTR policy in West Aceh District. From the initial survey, although most of the Health Office employees knew and supported the Qanun KTR policy in West Aceh District, smoking behavior was still found in buildings, especially in the West Aceh District Health Office. This happened because the building manager who was authorized to implement the Qanun on non-smoking areas in West Aceh District was still not maximal in the socialization of the QTR QTR. Whereas from the observations that the author made at the West Aceh District Health Office, a special place for smoking was provided for employees who wanted to smoke, but in reality there were still employees who smoked inside the building and were not sanctioned for smoking violations.

From the above problems, the implementation of Qanun KTR in the West Aceh District Health Office has not been carried out as expected. Implementation of QTR QTR will be carried out optimally if supported by adequate resources, clear communication between policy makers and implementers, disposition / attitude of policy implementation and structure of implementing bureaucracy policies that include the existence of standard operating procedures in the implementation of the Non-Smoking Qanun. 


\section{Literature Review}

Etymologically the notion of implementation according to Webster's Dictionary cited by Wahab that the concept of implementation comes from English, namely to implement. In a large dictionary webster, to implement (implement) means to provide the means of carrying out (providing a means to implement something) and to give practical effects to (to have an impact on something) (Webster in Wahab, 2009). Implementation comes from English which is to implement which means implementing. Implementation is the provision of means to implement something that has an impact or effect on something. Something that is done to cause an impact or effect can be in the form of laws, Government Regulations, judicial decisions and policies made by government institutions in state life (Wahab, 2009).

While Van Meter and Van Horn (1975 Agustino (2010) that implementation is actions taken by individuals or officials or government or private groups directed at achieving the objectives outlined in the policy decision. The views of Van Meter and Van Horn that implementation is an action by individuals, officials, groups of government or private entities that are directed towards achieving the objectives outlined in a particular decision.The agencies carry out government jobs that have an impact on their citizens. But in practice government agencies often face jobs under the mandate of the law, making it unclear to decide what should be done and what should not $b$

Furthermore, according to Sunggono (2009) the policy implementation process, can only be started if the policy objectives have been set, programs have been made, and funds have been allocated for achieving the policy objectives. Whereas according to Wahab (2009) policy implementation can be seen from the point of view of (1) policy makers, (2) executive officers in the field, and (3) policy targets (target group). The main concern of policymakers is to focus on the extent to which the policy has been achieved and the reasons that led to the success or failure of the policy. From the implementer's point of view, implementation will focus on the actions of officials and agencies in the field to achieve program success. While from the target groups' point of view, implementation will be more focused on whether the implementation of the policy really changes the pattern of life and has a long positive impact on improving the quality of life including their income.

\section{Implementation of George Edwards III Policy}

The theory put forward by Edwards is also called Direct and Indirect Impact on Implementation. According to Edwards, there are 4 (four) factors that influence the implementation of a policy that between one factor and another influences each other (Winarno, 2012), namely:

\section{a. Communication Factors}

A program can only be implemented well if it is clear to the implementers. This concerns the process of delivering information, information clarity and the consistency of the information submitted. All of these things can be obtained through effective communication.

\section{b. Resource Factor}

Although the contents of the policy have been communicated clearly and consistently, but if the implementor lacks the resources to implement, the implementation will not run effectively. 


\section{c. Disposition factor}

Disposition is defined as the attitude or perspective of the implementor in implementing the policy. If the implementors behave well or support a policy, they are likely to implement policies as desired by policy makers. But on the contrary, if the behavior or perspective of the implementor is different from the policy maker, the process of implementing a policy will be difficult.

\section{d. Factors of Bureaucratic Structure}

Basically, implementors might know what to do in implementing policies and have enough resources and desires but sometimes they are still hampered by the bureaucratic structure in which they carry out these activities.

\section{Non-Smoking Areas (Kawasan Tanpa Rokok in Indonesia)}

Non-Smoking Area, hereinafter abbreviated as KTR, is a room or area that is declared prohibited for smoking activities or activities in producing, selling, advertising, and / or promoting tobacco products (Ministry of Health, 2011).

The scope of the Non-Smoking Area according to the Indonesian Ministry of Health (2011), namely:
a. Health Service Facilities
b. Teaching and Learning Place
c. Children's Playground
d. Worship place
e. Public transportation
f. Workplace
g. Public places
h. Other Places Set

The purpose of establishing a no-smoking area is:

a. Realizing healthy and clean air quality free from cigarette smoke.

b. Change people's behavior for healthy living.

c. Reducing the number of smokers and preventing novice smokers.

d. Realizing a healthy young generation.

e. Increase optimal work productivity.

f. Reducing morbidity and / or mortality.

g. Protect children and nonsmokers from health risks.

h. Prevent discomfort, odor and dirt from the cigarette room (Ministry of Health, 2011).

\section{Cigarettes and Smoking}

According to Government Regulation Number 109 of 2012 concerning Safeguards of Materials Containing Addictive Substances in the Form of Tobacco Products for Health, cigarettes are one of the Tobacco Products intended to be burned and smoked and / or inhaled, including clove cigarettes, white cigarettes, cigars or other forms produced from plants nicotiana tabacum, nicotiana rustica, and other species or synthetics whose fumes contain nicotine and tar, with or without additives. Cigarettes are cylinders of paper measuring between 70 and $120 \mathrm{~mm}$ (varying by country) with a diameter of about $10 \mathrm{~mm}$ containing chopped tobacco leaves. The cigarette is burned at one end and allowed to burn so that the smoke can be inhaled through the mouth at the other end. 
According to Harissons (1987) in Sitepoe (2000), smoking is burning tobacco which is then smoked by smoke using cigarettes or using pipes. The temperature of a cigarette that is being burned is $9000 \mathrm{C}$ for the tip of the cigarette that is burned and 300C for the tip of the cigarette tucked between the smoker's lips. Smoked cigarette smoke or cigarette smoke which is inhaled through two components, namely components that quickly evaporate in the form of gases and components that together with condensed gas become a particulate component. Thus, the smoked cigarette is in the form of a gas of $85 \%$ and the rest is in the form of particles. Cigarette smoke smoked through the mouth is mainstream smoke, while cigarette smoke formed on the tip of a cigarette that burns and cigarette smoke exhaled into the air by smokers is called sidestream smoke. Sidestream smoke causes a person to become passive smoker. According to the Indonesian Ministry of Health (2011) passive smokers are nonsmokers but smoke or breathe cigarette smoke released by smokers.

\section{Method}

The research method used in this study is a qualitative method with a descriptive research design to explain the description of the research results in the form of words on research conducted by researchers regarding the implementation of Qanun in Non-Smoking Areas (KTR) at the West Aceh District Health Office.

The taking of research informants was done purposively on the basis of a particular consideration made by the researchers themselves at the West Aceh District Health Office based on the characteristics or characteristics of the population that had been previously known. In this study the number of research informants selected by the researchers amounted to 7 people consisting of 2 main informants and 5 triangulation informants namely:

a. The main informants were the Head of the West Aceh District Health Office and the Head of the Program and Promkes of the West Aceh District Health Office

b. Triangulation informants were 5 employees / staff representing the Head of the West Aceh District Health Office

Based on the data collected, data analysis techniques are carried out using relying on semantic aspects and words derived from the main information source. Milles and Hubermas in Silalahi (2009) state that qualitative with descriptive research design consists of three lines of activities that occur simultaneously, namely data reduction, data presentation and conclusion / verification.

\section{Result}

\section{Implementation of Qanun in Non-Smoking Areas in West Aceh District Health Office}

Based on the results of research that has been carried out on the implementation of the Qanun of Non-Smoking Areas in the West Aceh District Health Office, it is related to those who are responsible for implementing the KTR Qanun in the research interview that the researcher has done to the main informant. The West Aceh District Health Office is expected to be a pioneer responsible for implementing Qanun KTR in the West Aceh District Health Office. This was conveyed by the main informant 1 as the person responsible for the No Smoking Area at the West Aceh District Health Office, giving his response in this study, namely: 
First, the Head of the Health Office as the SKPK Chairperson who has full responsibility in implementing the KTR, then the mother who is appointed as the person in charge of the KTR implementation, then all employees here are also responsible for implementing the KTR (Main Informant 1).

Subsequent responses regarding the response to the Qanun of the No Smoking Area at the West Aceh District Health Office were presented by the main informant 2 who said that:

In the Health Office, it is all responsible, the most important of which is the Head of Service who must be fully responsible for the implementation of the Non-Smoking Qanun Area. When there are employees who smoke not in their place, they are the responsibility of the Head of Service. Because the one who later gave the sanction was the Head of the Office (Main Informant 2).

Furthermore, interviews conducted by the researcher with the main informants on the question of how successful the implementation of Qanun in the Non-Smoking Area at the West Aceh District Health Office was delivered by the first informant, namely:

For now, you can say, not all employees, there are still one or two who smoke in the workspace, not in the place provided, so the mother in charge of KTR comes to remind and reprimand those who smoke, directed so that they smoke on the spot provided (Main Informant 1).

The same response as stated by key informant 1 above, also the same as the opinion expressed by the main informant 2 who said that:

Here, on average, I no longer smoke in the room because I have been directed to the place provided at the entrance there. Maybe one or two were still smoking, they were reprimanded, reprimanded orally, repeatedly reprimanded. Well if not this is also called by the Head of the Service. Only a cigarette ashtray is no longer in the room. There may also be certain places, there are also cigarette ashtrays. But it takes time for us to change his behavior, maybe we just go berserk, angry (Main Informant 2).

Regarding the obstacles to the implementation of the KTR Qanun, in the interview of this study, the main informant 1 said that

"Barriers are not because there is no place already provided huh, maybe because there are employees who are still unconscious leaving the smoking habit in the room, even though there is a KTR Qanun (Informant Main 1). The main informant 2 in the interview said that "There are many obstacles, which people want to be told to stop like that, it is difficult for people to stop smoking" (Main Informant 2).

Whereas regarding guidance, supervision and sanctions for employees who smoke in the Health Office concerned with the implementation of the KTR Qanun, the main informant 1 in this research interview said that:

This is not right now, because it still takes time for further guidance, because employees need time too, in the future there will be guidance, this is just a new stage of socialization, so the problem of supervision is only at the stage of warning and 
directing, not until on giving sanctions as mentioned in the KTR Qanun (Main Informant 1).

In a further interview conducted by the researcher on key informant 2 related to coaching, supervision and sanctions for employees who smoked in the Health Office concerning the implementation of the QTR, the main informant 2 said that:

Now that is what we have not done, because the Qanun should be, a derivative regulation is formed instead of the Qanun, meaning that for this cigarette problem, not only the Health Office, but all related SKPK sectors must be responsible for the nonsmoking area problem (Main Informant 2)

The results of the interviews that the researchers conducted with trianggulation informants were related to the implementation of Qanun in Non-Smoking Areasin the West Aceh District Health Office it is known that in general all employees have supported the Qanun of NonSmoking Areas, but in the implementation of Qanun there is still a need for time to implement it properly. This was conveyed by a trianggulation 1 informant who said that:

Yes, in fact we are quite supportive with the birth of this QTR QA, but we are not as easy as turning our palms to implement it. Even though the Qanun has been formed, most of the colleagues have not yet utilized the building that has been built (Triangulation 1 informant).

Regarding the issue of the implementation of Qanun KTR in the West Aceh District Health Office, also presented by riangulation informant 2 who gave the following responses:

Not too good, but there have been changes from the past, just to be upgraded again (Triangulation informant 2).

The next interview that the researcher did with the triangulation 3 informant regarding the implementation of the QTR QTR in the Health Office was obtained from the informants:

The employees here have supported the existence of Qanun KTR, even though the implementation has not run smoothly, because even though the employees already know and support the Qanun KTR, it is still very difficult, because sometimes there are also employees who still smoke (Triangulation Informant 3 ).

The triangulation 4 informants related to the implementation of Qanun KTR at the Health Office, giving their opinions, as follow:

Regarding Qanun KTR, all the colleagues here already know and support the implementation, only for now we still need time to discipline our colleagues so they don't smoke in the room. There are still one or two who sometimes smoke in the room. So it needs time to apply the KTR Qanun (Triangulation Informant 4).

Another opinion was also conveyed by trianggulation informant 5 in response to the researcher's question regarding the implementation of Qanun KTR in the West Aceh District Health Office, namely: 
The implementation was not so smooth, maybe because for the implementation not all employees were smoking, there were still smoking, it was only limited to getting reprimand from work colleagues. Whereas if there are no leaders (Triangulation Informant 5).

Regarding the form and supervision of the Qanun of the Non-Smoking Area in the West Aceh District Health Office, from the interviews the researchers conducted on 5 (five) triangulation informants showed that at the West Aceh District Health Office, there had been socialization about Qanun KTR, but for now from the results of research that researchers have done at the West Aceh District Health Office there has not been implemented guidance and supervision of the KTR QTR. This is as revealed by trianggulation informant 1 in this research interview which said that:

In the internal scope, actually we have not, only we have previously made socialization, but almost all people know, only if we are sorry that our friends have not fully implemented because there may not be sanctions, even though administrative sanctions, but most already know (Informant Triangulation 1).

From the next interview the researchers did, a different response was responded to by trianggulation informant 2 who said that:

There is. Direct supervision is also available. It's just that sometimes the awareness of our fellow humans will be reprimanded if someone smokes in that room (Triangulation Informant 2).

Another response was also conveyed by triangulation informant 3 in the research interview that the researcher did concerning the guidance and supervision related to Qanun KTR, saying that:

If special guidance is carried out by the Health Office, it is not available to all employees, but we have conveyed it to socialization, such as for example if employees who smoke we remind them that there is now a special place for smoking (Triangulation Informant 3).

In the next interview, it was related to the same question that the researcher asked the triangulation informant 4 , saying that:

Guidance does not exist yet, because all the employees of this KANun have known the KTR Qanun. All that remains is the implementation that must be maximized (Triangulation Informant 4).

Another comment was conveyed by trianggulation informant 5 in the research interview that the researcher did regarding the guidance and supervision in the implementation of the QTR QTR. In this case the trianggulation informant 5 said that:

Yes, it was like that, right, because the implementation was not smooth as stated in the Qanun, so if anyone smoked in the room, just being reprimanded, there was no sanction as mentioned in the Qanun (Triangulation Informant 5).

Based on the results of the research interviews presented by the 5 (five) triangulation informants above, it was known about the guidance and supervision in the implementation of 
the Qanun of Non-Smoking Areas in the West Aceh District Health Office that at this time in the Aceh District Health Office. The West has not carried out maximal guidance and supervision, because according to the informant regarding the Qanun of Non-Smoking Areas after the socialization of the Qanun, only limited to the delivery of reprimands by fellow employees if there are employees who smoke in the workspace.

Regarding the application of sanctions for violations of Qanun in Non-Smoking Areas in the West Aceh District Health Office, from the interviews conducted by researchers on 5 (five) trianggulation informants indicated that there had been no sanctions as stated in the Qanun by the Head of Office for employees. This matter, concerning the sanctions for violating the Qanun, a triangulation 1 informant said that:

Of course if sanctions are initially administrative sanctions, they can be from reprimand, only, but not yet, there has not been any sanctions (triangulation informant $1)$.

Other responses were also raised by triangulation 2 informants who in this research interview said that:

There is no sanction. Just a warning. If for example, sometimes it would be nice if there were no more people, sometimes smoking too. But if you know that, just be reprimanded (Triangulation Informant 2).

The next interview that the researcher did with triangulation 3 informants in this study stated that there had been no specific sanctions imposed as stipulated in the West Aceh Regency KTR Qanun. This is as a comment that is conveyed, as follow:

For special punishment, such as the absence of fines for those who smoke, there are none, only we warn that employees who smoke do not smoke in the room work, there has been a special place for smoking for those who smoke (Triangulation Informant $3)$.

Regarding the issue regarding sanctions for violations of the West Aceh Regency KTR Qanun, a triangulation informant 4 who in this interview said that:

For now, sanctions as mentioned in the Qanun KTR have not been implemented, if anyone smokes is only reprimanded so as not to smoke in the room, if smoking please in the provided space, like that (Trianggu Informant 4).

As for further interviews with researchers conducting triangulation 5 informants regarding violations of the implementation of the West Aceh Regency KTR Qanun by Aceh District Health Office staff, it was said that:

Sanctions for colleagues who smoke because they violate the Qanun do not yet exist, yes, most of us, if we see a colleague who smokes, we only scold, so we don't smoke in the workspace (Triangulation Informant 5).

Based on the results of interviews conducted by the researchers on 5 (five) trianggulation informants, then regarding sanctions for violations of the implementation of the Qanun of the Non-Smoking Area by West Aceh District Health Office staff indicated that no violations had 
been made at this time. by the Head of the West Aceh District Health Office. From the results of the study that employees who violated Qanun or in the sense of words when found there were employees who smoked indoors, the effort was made to give a warning to the person not to smoke in the room, as stipulated in the Qanun of the Non-Smoking District of West Aceh.

\section{Communication Clarity in the Implementation of Qanun in Non-Smoking Areas in the West Aceh District Health Office}

Based on the results of research conducted on research informants that the implementation of Qanun in Non-Smoking Regions is very clear because it relates to communication of the Head of Service as the person in charge of Qanun KTR to employees, the information has been clearly conveyed, as the results of research interviews conducted on main informant 1 saying that:

Since the start of the QTR, the KTR has been approved and stipulated by the Government, we have communicated by the Head of the Office so that the Qanun will be immediately disseminated to all staff staff at the Health Office. We also provide special places for employees who smoke, to smoke in the places provided (Main Informant 1).

In the next interview the researcher did with the main informant 2 regarding the communication of the Head of Service as the person in charge of Qanun KTR towards the employee:

Information about the area without cigarettes is always given during the morning apples, delivered do not smoke carelessly, not forbid people to smoke, but smoke in the places provided (Main Informant 2).

From the interviews presented by the main informant above regarding the clarity of communication provided by the Head of the Office, it was revealed that Qanun KTR, from the outset the KTR QTR was ratified and stipulated by the Government, we had communicated by the Head of Office so that the Qanun was immediately disseminated to all staff staff and the information was delivered every morning, as a form of Qanun implementation, so that employees do not smoke in the work room. As for further interviews the researchers conducted on 5 (five) trianggulation informants relating to the communication of the Head of Service as the person in charge of Qanun KTR to employees in the Health Office, in this research interview, informant triangulation 1 said that:

If for now it doesn't, the intention is to be notified from the beginning, when socializing when the Qanun is formed, although sometimes we have forgotten, if not repeated and reminded (Triangulation Informant 1).

In connection with the problems previously stated by the informant above, then in a further interview the researcher did with the trianggulation 2 informant, conveying his opinion, as follow:

There is no communication if there is particular communication, there is socialization at the beginning of the Qanun KTR set, that is what exists, and the socialization was also conveyed at the morning applause, notified every morning so that employees do not smoke in the workspace (Triangulation Informant 2). 
In the next interview that the researcher did with informants triangulation 3 , the clarity of the communication provided by the Head of the Service indicated that the QTR, said that:

The head of office communication with employees was smooth, because since the QTR Law was passed, the head of the agency had notified all employees and the socialization was also made for a special KTR pamphlet (Triangulation Informant 3).

Whereas triangulation 4 informants related to the clarity of the communication provided by the Head of the Service indicated that the QANun KTR, said in the interview this study that:

For now, the head of department communication with subordinates is normal. It is true that if the implementation of the KTR Qanun has been communicated for a long time, the employees already know everything (Triangulation Informant 4).

Further interviews with trianggulation 5 informants regarding the clarity of the communication provided by the Head of the Office indicated that the QTR QTR, said that:

The Head of the Office has communicated about the implementation of Qanun and its implementation must be implemented in the Health Office, it has long been conveyed, but because the problem of smoking has long been a habit because there are still smoking, maybe in the future it must be communicated back to employees here (Triangulation informant 5).

Based on the results of the interview presented by the 5 (five) triangulation informants above, the clarity of the communication provided by the Head of the Office was that it was related to the clarity of communication that it was very clear from the socialization of the KTR Qanun when the Qanun was stipulated, which was then socialized on the internal Office Health of West Aceh Regency, so that from the communication that has been done, then all employees have learned from the points of implementation of the West Aceh Regency KTR Qanun.

\section{Authority in the Implementation of Qanun in Non-Smoking Areas in the West Aceh District Health Office}

Based on the results of research interviews that researchers have conducted regarding the authority in the implementation of Qanun of Non-Smoking Areas in the West Aceh District Health Office, in interviews conducted with the main informant 1, it was conveyed that:

The implementation of the QTR QTR is the authority of the Head of the Service, both from coaching, supervision or sanctions, because as the SKPK leader, he is responsible for the successful implementation of the QTR in the Health Office (Main Informant 1).

Whereas the next interview that the researcher did with the main informant 2, said that:

Yes, that is exactly what you said earlier, if the full authority of the implementation of Qanun KTR is the responsibility of the Head of the Health Office. Yes, either from coaching, supervision or sanctions to those who violate the KTR Qanun (Main Informant 2). 
In interviewing the next research the researchers conducted on 5 (five) trianggulation informants, that in general all trianggulation informants gave their comments regarding the issue of authority in the implementation of the QTR Qanun was the responsibility or authority of the Head of the West Aceh District Health Office. This was conveyed by a trianggulation 1 informant who said that:

Authority of Head of Service in the implementation of Qanun KTR at the Health Office. He is fully responsible for implementing the KTR Qanun (Triangulation Informant 1).

The trianggulation 2 informant in his interview with researchers in this study said that:

The Head of Service has the authority to provide, especially those sanctions for employees who violate the KTR QTR (Triangulation Informant 2).

Based on the interview delivered by triangulation 1 and 2 informants it was found that the authority regarding the implementation of Qanun KTR in the West Aceh District Health Office was the authority of the Head of Service asfully responsible for implementing KTR at the Health Office. The next interview that the researcher did with triangulation 3 informants said that:

The application of KTR in the Health Office is the authority of the Head of the Health Office to implement it according to the KTR Qanun (Triangulation Informant 3).

The trianggulation 4 informant related to the above, commenting that:

The issue of the authority to implement the Qanun KTR, is here the authority of the Head of the Office. Only so far, right because it is only possible, the stages needed to implement KTR are better (Triangulation Informant 4).

Whereas in further interviews the researchers did with triangulation 5 informants said that:

Of course, the implementation of the Qanun KTR was the authority of the Head of the Health Service (Triangulation Informant 5).

Based on the results of interviews that have been conveyed by the triangulation informants above, that the authority in implementing Qanun KTR in the Health Office is the responsibility of the Health Office, in providing direction on KTR guidance and supervision as well as sanctions for employees who violate the QTR QTR.

\section{Disposition in the Implementation of Qanun in Non-Smoking Areas in the West Aceh District Health Office}

Based on the results of research interviews conducted by researchers regarding the disposition (attitude) of employees in implementing the Qanun of Non-Smoking Areas in the West Aceh District Health Office, that generally employees have supported the implementation of the Qanun without Smoking Area (KTR), howeverin its implementation there is still an attitude of employees still smoking in the room, not in the place that has been provided, because employees have smoking habits indoors. This was conveyed by the main informant 1 in this research interview, who said that: 
Now the smoking habit of employees in the work room has begun to no longer exist, even the cigarette ashtrays have been forbidden to be placed in the workspace, we have also put all the work spaces written "No Smoking Here", we do this so that employees get used to not smoking anymore in the room . Even if we still remind us, we scold, we direct, so they don't smoke in the room (Main Informant 1).

The next interview that the researcher did with the main informant 2 was related to the attitude of the informants regarding the implementation of the QTR QTR and there were still employees who smoked in the Health Office, in this case the main informant 2 said that:

It is still difficult because if there is still one or two who still smoke in the room, even though we have directed to smoke in an existing place, then we can only reprimand it verbally, because as mothers say it takes time to change their attitude so as not to smoking in the room (Main Informant 2).

The next interview that the researcher conducted on 5 (five) trianggulation informants related to the disposition (attitude) of the employees in the implementation of the Qanun of the No Smoking Area in the West Aceh District Health Office, was delivered by informant trianggulation 1 who said that:

Yes, I think smoking is basically human rights, but sometimes even in human rights, it can also interfere with others. But if I am, it is the core of Qanun KTR, smoking does not require people to stop smoking, but orderly smoking, does that mean there is already a place, if we are not happy with cigarette smoke, then we will move (Triangulation Informant 1)

Furthermore, it relates to the questions the researchers submitted related to the disposition (attitude) of employees in the implementation of the Qanun of Non-Smoking Areas in the West Aceh District Health Office, delivered by trianggulation informant 2 who said that:

I cannot forbid people to have smoking habits, but because in Qanun it has been stated that they do not smoke in the room, but smoke in the space provided, but because maybe because they used to smoke in the room, maybe the people were difficult, so if there is who smoked, I just rebuked it (Triangulation informant 2).

The trianggulation informant 3 is related to the issue of disposition (attitude) to employees in the implementation of the Non-Smoking Qanun Area, saying that:

I think smoking is okay, no one forbids here not to smoke, but at least employees know that smoking, smoke in the place provided (Triangulation Informant 3).

Whereas from the results of the next interview the researcher has done with triangulation informant 4 , in this case saying that:

Smoking can interfere with the health of yourself and others. In my opinion, the KTR QTR does not prohibit people from smoking, but prohibits people from smoking in certain places that can interfere with the comfort of others around them (Triangulation Informant 4). 
Whatever the triangulation informant 5 was in the further research interviews that the researcher did, the informant said that:

If I hope that employees can obey so they don't smoke, they must be disciplined, the smoking rules already have Qanun. If you want to continue smoking, smoke in a place that already has a place (Informant Triangulation 5).

Based on the interviews that the researchers had done with the main informants and the triangulation informants above regarding the disposition (attitude) of employees in the implementation of Qanun in the No Smoking Area at the West Aceh District Health Office showed that the attitudes of employees in the West Aceh District Health Office still did not comply with Qanun implementation, it is known from the existence of employees who smoke, even though they have received a warning from another employee colleague. The attitude of not adhering to the implementation of Qanun is due to the old habits that are embedded in employees who smoke in the room before the Qanun, so according to the informant above, it is very difficult for employees to change the old habit of smoking indoors to be moved to the location provided for employees who smoke.

\section{Standard Operating Procedure in the Implementation of Qanun in Non-Smoking Areas in the West Aceh District Health Office}

Regarding the Operational Standards (SOP) as a draft institution to regulate further implementation related to the implementation of Qanun in the No Smoking Area specifically at the Health Office, from the interviews the researchers had done with the main informants and trianggulation informants it was known that the Health Office did not have an SOP, for reasons that Qanun KTR has very clearly reported the rules relating to the implementation of non-smoking areas for all District Government Work Units (SKPK). This mattercan be seen from the results of interviews that the researcher did with the main informant 1 , who gave his comments namely:

Now there is no SOP yet, for now KTR is implemented in accordance with the Qanun, and the rules are complete, if indeed later SOP is needed as an internal reference for the Office for further implementation, we will coordinate the preparation (Main Informant 1)

Another response to the SOP was also conveyed by key informant 2 who said that:

There is no SOP without smoking area, the application is still based on the first Qanun, Qanun is all complete, only the implementation of sanctions that have not yet been implemented, because all this time has only been given a reprimand, but further sanctions have not been implemented, so mother said it needed a Perbub (Regents of Regents) derivative again (Main Informant 2).

The results of interviews conducted by researchers with trianggulation 1 informants related to the Standard Operating Procedure (SOP) in the implementation of Qanun in Non-Smoking Areas in the West Aceh District Health Office, obtained answers from informants as follows:

I don't think there is a need for an SOP anymore, because Qanun clearly regulates everything, because there are many articles and verses that have governed nonsmoking areas (Triangulation Informant 1). 
Based on the results of interviews that have been delivered by the main informants and the above triangulation informants regarding the Standard Operating Procedure (SOP) in the implementation of the Non-Smoking Qanun in the West Aceh District Health Office, it is known that at present there are no operational standards for procedures that govern procedures the implementation of the Qanun of Non-Smoking Areas in the West Aceh District Health Office. The absence of SOPs, according to information conveyed by informants because in Qanun it is clear enough to regulate how to implement and implement areas without cigarettes.

\section{Conclusion}

Based on the results of the research, the conclusions of this study are:

1. Implementation of Qanun in Non-Smoking Areas in the Health Office is still not maximally implemented due to the absence of guidance and supervision on the implementation of the KTR Qanun so that there are still employees who still smoke in the room, as well as the absence of sanctions for employees who smoke.

2. Aspects of communication clarity in the implementation of the Qanun of the West Aceh District Health Non-Smoking Area are known that the application of the Qanun KTR has been submitted every morning by the Head of the West Aceh District Health Office that employees are no longer allowed to smoke in the workspace.

3. The aspect of authority for the implementation of the Qanun of the West Aceh District Health Non-Smoking Area that the Implementation of the QTR QTR is the authority of the Head of the Service in guidance, supervision or sanctions.

4. Aspects of the implementation attitude Qanun West Aceh District Health Non-Smoking Area is known to employees less obedient to implement the KTR Qanun because employees still smoke not in the place provided.

5. Standard Operating Procedure (SOP) for the implementation of Qanun for Non-Smoking Areas in the West Aceh District Health Office. It is known that the Health Office does not have standard operating procedures to regulate the implementation of Qanun without smoking areas specifically at the West Aceh District Health Office.

\section{Author Contribution and Competing Interest}

The first, second, and third author played major role in conducting the research. The rest of the authors helped in analyzing the data, preparing and finishing the manuscript.

\section{References}

Agustino, L. (2010). Dasar-Dasar KebijakanPublik. Alfabeta. Bandung.

Depkes RI, (2010). (2010). Kajian

RisetOperasionalIntensifikasiPemberantasanPenyakitMenular.DepartemenKesehatanR I.Jakarta.

Gundodiputro. (2007). BahayaTembakau dan Bentuk-BentukSediaan.

FakultasKesehatanUnversitasPadjajaran. Bandung.

Kemenkes RI. (2009). Undang-UndangNomor 39 Tahun 2009 tentangKesehatan.

Kementerian Kesehatan RI. Jakarta. 
. (2011). Peraturan Bersama Menteri Kesehahatan dan Menteri Dalam Negeri TentangPedomanPelaksanaan Kawasan TanpaRokok. Kementerian Kesehatan RI. Jakarta.

Moleong, J. Lexy. (2013). MetodologiPenelitianKualitatif. RemajaRosdaKarya: Bandung. Paper, Policy. (2012). Kawasan TanpaRokok Dan Implementasinya. TCSC.Jakarta.

PeraturanPemerintahNomor 19 Tahun 2003 tentangPengamananRokokBagiKesehatan.

PermenkesNomor 188/MENKES/PB/I/211 tentangPedomanPelaksanaan Kawasan TanpaRokok

Poerwadarmita. (2012). KamusUmum Bahasa Indonesia. BalaiPustaka. Jakarta.

QanunKabupaten Aceh Barat Nomor 14 Tahun 2015 tentang KTR

Silalahi, Ulber. (2012). MetodePenelitianSosial. RefikaAditama. Bandung.

Sitepoe, M. (2000). KekhususanRokok di Indonesia.Grasindo. Jakarta.

Undang-UndangNomor 39 Tahun 2009 tentangKesehatan

Wahab, Solichin. (2009). AnalisisKebijakan Dari FormulasiImplementasiKebijakan Negara. BumiAksara. Jakarta.

Winarno, Budi. (2012). KebijakanPublikTeori, Proses dan StudiKasus. CPAS. Yogyakarta. WHO. 2011. WHO Report On The Global Tobacco Epidemic 2011: Warning About the Dangers of Tobacco. Geneva: WHO Press. 